\title{
"Writing is essentially a very, very innocent thing": In Conversation with Marina Carr
}

\author{
Melania Terrazas Gallego \\ University of La Rioja, Spain
}

Copyright (c) 2019 by Melania Terrazas Gallego. This text may be archived and redistributed both in electronic form and in hard copy, provided that the author and journal are properly cited and no fee is charged for access.

\begin{abstract}
Marina Carr participated in the Conference "Irish Itinerary 2018 (EFACIS): Trauma and Identity in Contemporary Irish Literature and Culture" at the University of La Rioja. The following interview took place there on 13 February 2018, covering issues of gender, trauma, identity and travellers in an Irish context. Greek tragedy and myth, and Spanish adaptations of Marina Carr's plays and creative writing were discussed as well. Carr offers a number of insightful responses and shares her views on gender, relationships and her motivations to write.
\end{abstract}

Key Words. Marina Carr, Theatre, Gender, Greek Tragedy, Trauma, Irish Travellers and Creative Writing.

Resumen. Marina Carr participó en el Itinerario Irlandés 2018 de la Federación Europea de Asociaciones y Centros de Estudios Irlandeses (EFACIS) titulado "Trauma e identidad en la literatura y cultura irlandesas contemporáneas", celebrado en la Universidad de La Rioja. La entrevista siguiente tuvo lugar allí el 13 de febrero de 2018 y se le hicieron preguntas acerca de género, trauma, identidad y nómadas en el contexto irlandés. También se trataron aspectos de tragedia y mitos griegos, y las adaptaciones de sus obras teatrales al español y escritura creativa. Carr ofrece unas respuestas muy clarificadoras y comparte de manera sincera sus opiniones sobre cuestiones de género, relaciones humanas y sus motivaciones como escritora.

Palabras clave. Marina Carr, teatro, género, tragedia griega, trauma, nómadas irlandeses y escritura creativa. 
Dublin-born playwright Marina Carr is an elected member of Aosdána, the Irish association which honours distinguished artistic work. She has been writer-in-residence at the Abbey Theatre and has taught in different universities around the world, including Trinity College Dublin, Princeton and Villanova.

Carr's widely acclaimed work has frequently addressed feminist considerations in order to explore Irish society. It has been translated into many languages and received numerous awards. The most recent, the Windham-Campbell Prize, was presented to her in September 2017. Carr is the second Irish author to receive this prize. She has published three collections of plays with Faber and Faber. The first launched her as a major new voice ${ }^{1}$ in theatre and includes Love in the Dark, The Mai, Portia Coughlan and By the Bog of Cats. Carr's second collection includes On Raftery's Hill, Ariel, The Cordelia Dream, Marble and Woman and Scarecrow. The third, and richly varied, collection was published to coincide with the Royal Shakespeare Company's premiere of Carr's Hecuba at the Swan Theatre, Stratford-upon-Avon, in September 2015. It contains five plays: Sixteen Possible Glimpses, Phaedra Backwards, The Map of Argentina, Indigo and Hecuba.

Besides these published works, Marina Carr has been commissioned to write over 20 dramas for the Royal Shakespeare Company, the Abbey Theatre, the Royal Court, London, the Peacock, Dublin, and the Dublin Theatre Festival.

Melania Terrazas: Marina, thank you very much for accepting the invitation to be a Keynote Speaker at Irish Itinerary 2018 and agreeing to this interview. I would like to start with a few general questions before I focus on some specific plays in more detail. When and how did your writing adventure start?

Marina Carr: Oh, my God! It was so long ago, I'll try to remember. I started writing as a child. We built a theatre in the shed at home. We'd put up our own plays, we wrote them and directed them, we made costumes and we invited our neighbours, who came and sat in. And when I was in school, I wrote a school play. And then I went to University College Dublin. I was involved in the Drama Society there. And then I wrote my first play in my final year in college. That is how it began... very early.

MT: Many critics describe your style as darkly funny. You make frequent use of irony, wit, fantasy, and animal and dystopic imagery. Do you consider yourself a satirical author?

MC: No! Not at all! I don't know what I am! You just sit down and you write. I suppose irony, humour, dark humour is a very Irish way of looking at the world. You know, when you are writing, you try not to second-guess yourself and you are not sure, but I am really glad that you mentioned wit. There is wit and humour in there. A lot of the world is so dark, so it's very refreshing to hear it, and it is lovely that it has come across in the Spanish translation of Marble, which I saw at the National Theatre in Madrid, and then I saw it in Nieva Theatre. I don't know how I describe myself. I thought of Jonathan Swift when you mentioned satire, he is a brilliant satirist but it's not something that I have ever consciously aimed for.

MT: In the first decade of the twenty-first century, several Irish women playwrights have explored a type of fiction that attempts to place Irish women back into a history from which they have been often written out. You have frequently addressed feminist considerations in your work in order to transform ideas of what Ireland was, is, and can be, and considered your formal experimentation with theatre is crucial to this end. Do you agree with this assessment? What challenges did you face when you started writing? 
MC: I was so green when I started. I did not think the world had challenges. I just sat down and wrote a play. To be honest, it is kind of difficult to avoid some of the interpretations of your work, it is difficult not to hear, but I think the more you can avoid engaging on that level, the freer the work is, and the more open. I never considered myself a feminist writer when I started writing. I think I hardly knew what feminism was. I started writing very young and I look at my students now and they are so much more aware than I was at their age. I suppose I came through in an age where you were terrified of your professors, you hardly opened your mouth, and you never really asked questions; they gave you a grade, and you just went off. That was just the culture at home, it was very hierarchical. I think it's more open and freer now, but to answer your question, yes I would agree with your interpretation absolutely, but it is not something you think about when you're writing. I don't think it's the first impulse to consider how this would be interpreted. And I think it's probably very damaging if you are trying to write and you are second-guessing and thinking, "How this will come across?" I think if you can keep your mind clear of all those "isms", all those possible interpretations, the freer you will be, because writing is essentially a very, very innocent thing. The process of creation, writing plays, you are making it up. Yes, of course, everything you have read, everything you have experienced, is there in the mix, but I think the less you try to tie it down too early, the better. That is the type of writing I like. Of course, there are all the other different forms and if you are a polemicist, you have to be aware, you have to know all this stuff. But I have - I think - a glorious freedom because I'm a playwright and I don't have to engage critically with the Academy, or even outside the Academy, because that would stop me writing.

\section{MT: You write about women, men, children - about the Irish people and broader society. In many of your plays, women want to escape society's constraints, but they do not - well, Catherine does in Marble. Do you think that theatre has the power to challenge the status quo?}

MC: Yes, I think the theatre can probably contain everything. It is the oldest art form, after all. Most plays in the history of theatre have been written by men. So if you come along, the very fact that you are of a different gender, different mind-set, in a different era, your concerns are automatically going to be different. Unconsciously, you are going to go against the status quo. It is the very fact that you are a woman writer. For about thirty years, since I started writing, I have been called a "female playwright". You never hear anyone called a "male playwright". I have been arguing this for decades and only in the last year have they stopped calling me female playwright. For me, that is a huge step forward, because I always feel that when people talk about my work, they feel they have to qualify and somehow apologise or explain me a bit, before they can engage. For me, that has been a huge achievement. Just, simply, to be called "playwright". It might appear a small thing, but language, as we know, is all pervasive and it signifies different things to different people, and there is something about that qualification in gender that I find humiliating - inexcusable, actually. Equality will not happen in my lifetime and I'm sorry to say but I think it probably will not happen in your lifetime either. I think it will take some hundreds, thousands of years. I think we are more than half of the human race, but this is the long, long argument. It's hardwired and it's going to take a massive, massive rearrangement of all our thinking for that to happen. 
MT: You often focus on women's lives, but not exclusively. There are some notable male characters, and they are not always portrayed very positively. Would you say that gender issues are a key motif in your writing?

MC: Well, it's impossible not to be aware of it now. I prefer to be less aware of it, but I suppose this whole argument is so huge, and you have to be so careful how you speak, to be honest, because where is it going to take us? Who was it who said - an American woman, I forget her name - that we have to be ten times better to be thought half as good? I think there is a lot of that. A man of my age writes the whole spectrum. It is a given that he can write about anything and equally well. I think it is a conscious way of controlling and qualifying and making women's writing somehow lesser. So I would refute that I write about women, I write about people. I write about men, I write about women, I write about children. The focus right now, because of the whole gender war going on, happens to be that I write about women and that is fine. Hopefully, in time, that will change. It's out of my control. It's the way the work has been interpreted, since I started to write. So my only defence really is to keep writing, and I think for women who are creators, women who are in creative positions in the theatre, their only defence is just to keep working, keep working away quietly, keep doing what you do, and eventually the culture will shift.

\section{MT: How would you describe the challenges facing men and women in Ireland today?}

MC: Oh, God, no worse than usual, probably. To live well is always a challenge, isn't it? All the other stuff is there, but there are always variations. I stopped reading newspapers about ten years ago, because I realised the stories were the same, just the locations kept changing.

MT: You have spoken in interviews about the influence of Euripides on your plays. Euripides is usually identified with theatrical innovations that have profoundly influenced drama down to modern times, especially in the representation of traditional, mythical heroes as ordinary people in extraordinary circumstances. This approach led him to focus on the inner lives and motives of his characters in a way previously unknown. Euripides was also unique among the playwrights of ancient Athens for the sympathy he demonstrated towards victims, including women and foreigners. His conservative male audiences were frequently shocked by the "heresies" he put into his characters' mouths, such as the thoughts expressed by Medea. In By the Bog of Cats, you apply theatrical innovations to reinvent Euripides' Medea in order to explore the position of women in post-independence Irish society. ${ }^{2}$ For example, Hester Swane is a Traveller, a marginalized figure in the mould of Medea, who was viewed as a barbarian.

MC: I also re-wrote his Hecuba. His Medea, I love. Actually, the three Athenean tragedians were actually the first feminists. They were the first ones that gave half the voice to women I mean Aeschylus, Sophocles and Euripides. These women are so articulate, they are so eloquent, they are transgressors, they take power, because power is not allowed them, and they will it, they can argue like men. It was one of the attributes they most cherished in Athens, this eloquence, this ability to argue, oratory, and what Aeschylus does with Clytemnestra, Sophocles to a lesser extent with Iocasta, what Euripides does with Hecuba and with Medea, is to make these women powerful speakers. Theirs was the quality most cherished in men besides being a great soldier, physical fitness and physical beauty, and this ability to speak to will, to use language as an effective tool, to enchant with language, to intoxicate with language and that is what these three tragedians have these women characters do in their plays. They give them the attributes that were revered in men at the time. You have 
to remember that women were slightly above slaves and that is a very powerful thing, and then, you think about the audiences, they were men and boys, and a few visiting foreign dignities who may have been women. So, yes, very powerful.

\section{MT: What kind of heroines are you interested in?}

MC: In Bog of Cats, the only thing I wanted for Hester Swane was that she would have an answer for everything. So no one was going to do her down, basically. She was going to answer everything. I didn't know that this is what Euripides had done with Hecuba, had done with Medea, what Aeschylus had done with Clytemnestra in Agamemnon. I mean, I'd read the plays. Obviously something had gone in, because you look at these plays, you look at these women and they have an answer for everything. They are articulate. They can express how they feel and, I suppose that is in a way why we are here, to be able to express how we feel.

MT: I love that answer. Was By the Bog of Cats difficult to write? I ask because the story is about Travellers and living on borders and this requires getting into the psyche of an unknown part of the population.

MC: I can't remember it being particularly difficult. I did four drafts, so it changed a lot. But I tend to do that in most of my plays. Then again, it is different every time. Some plays come effortlessly and with some you are dragging, it is like dragging a bag of potatoes on your back, for a couple of years; or digging, you are trying to find the gold. So it is different every time, but I don't think that one was particularly difficult. It wasn't particularly easy either. There were a lot of drafts that I was re-working, you know, I read it back and writers, I think, hate reading their work afterwards: all you can see is what is wrong with it. I wouldn't touch it now. It's there, it is what it is. You move on, you try and improve your next play. I can see parts where I think I overwrote, maybe.

MT: In By the Bog of Cats, Hester and Josie are Travellers, marginalized outsiders who face discrimination. But you experiment with a mythical approach and other formal devices to represent them in a very respectful manner. Other representations of Travellers by settled authors are often less respectful, quite biased. ${ }^{3}$ Did you write Hester and Josie to open up an ethical and political inquiry into the lives of Irish Traveller women?

MC: That's a really interesting question. Where I grew up, there was a Traveller woman, Rebecca, who was a friend of my mother. They would land with their caravan, she would feel that she should visit my mother. My mother used to take her to the sitting room and talk to her, and we would be left in the kitchen with some of her children, lots of children, and she and my mother would talk for hours and this would happen a couple of times a year maybe. I was quite young at the time. I never did any research on Travellers, but, maybe through my mother, and through just mixing with these Travellers, I never felt that there was much difference. I am glad you think there is respect there, because that would always worry me, particularly in this PC world, but it never felt like there was much difference. I felt we were more kin than different. We all have our little problems with status and where we are in the pecking order or what class we are. I don't know how class-ridden Spain is, but I imagine it is quite a class-ridden society. Ireland is. When you are a writer, you're an outsider anyway. You're a bit of a Traveller yourself. You never feel that you are involved in status because you are outside of it. And I suppose I've never thought about this, but I suppose, like Travellers, writers are always being judged! People always have opinions about you, about 
your work. There are negative and there are positive, but there is a lot of negative you have to deal with as a writer. I don't think it is particularly a gender thing. So, accessing someone like Hester Swane is not difficult.

MT: At the end of By the Bog of Cats, Hester kills her daughter. What effect were you seeking? What were you saying with this brutal act?

MC: Oh, it all comes down to "you trust the tale, not the teller" (D. H. Lawrence). Because I write it, it doesn't mean I'll agree with it. I think there has been a lot of confusion in the last fifty, sixty years, between the writer and what the writer writes. I think we are very quick to equate the writer with what they write. I try not to make that mistake when I am reading other writers. It is a difficult one because you want to identify, and you want to feel that you understand where this is coming from, but I think it is a mistake. It's also in the news. I don't know how it is in Spain. In Ireland, every year we have a couple of these, a mother killing her child. Recently, we had a whole phase of fathers killing their children and their wives. It is rare for the woman to kill her child, but we recently saw a case where a psychiatrist or a medical doctor drowned her daughter in the bath. You know tragic cases but it is not like this happened two and half thousands years ago. Human nature changes very little. That's one of the reasons I love all the myths. We have not changed that much. The passions are still raging in us all. The idea of family, love, right, wrong, all these questions that they try to tackle, they are still with us and we are still as far from the answers as we were then. The whole idea of fate and belief. Medea is a great argument around the rightness or wrongness of Medea's act in killing her own sons, the chances are they would not have been left alive anyway, had she not killed them. All these big questions; I don't have any answers. I just have more questions. I don't know where I stand on any of it, to be honest.

\section{MT: Many of your characters suffer from post-traumatic stress disorder after experiences and relationships that affect their identity?}

MC: I suppose that life is trauma, isn't it? We are all survivors of trauma. Things happen and you try and deal with them as best you can. Because I write through the theatre, because it is drama, it is heightened and it is artificial. You wonder what it is that keeps us going back to the theatre, and I think that it's something to do particularly with tragedies, plays that usually end in the death of our protagonists, our hero or our heroine, and I think that maybe the reason we love to watch tragedies, is because in our own life, we don't get to see the beginning of our lives and we don't get to see the end. So we are always in the middle. I think there is something very satisfying about that because, whether we accept it or not, we are all only going one way, we are all going to die, and that is tragic in itself. Forget about someone knifing you in the dark, the very fact that we are mortal is tragic, that we are here for a very, very short time, that we don't know when or how our exit will happen. Hopefully, it will be peaceful, you would wish that for everyone. Hopefully, it won't be violent. But I think that trauma is a fact of life, and theatre is about conflict. Theatre is about trauma and I'd love to write a play where everyone is completely happy, the whole time, but I can't. Ha ha! I haven't been able to yet.

MT: Your play Marble was translated into Spanish as Mármol and directed by Antonio C. Guijosa for his theatre company El Vodevil. The production featured Pepe Viyuela, José Luis Alcobendas, Elena González and Susana Hernández, and was first performed in Teatro Bretón, Logroño, in September 2016. You saw Mármol in Spain twice. Were you happy with the final production? How did it feel to watch a Spanish version of your 
work? Are any of your other plays being translated into Spanish, and adapted and performed in Spain?

MC: Yes, I loved it. They are fantastic actors. I had a great time. I thought it sounded beautiful in Spanish. I don't speak a word of Spanish. I just loved the conversation, the actors. It was really hard to make it work and I really love and respect their effort. It is wonderful if the work translates into another culture. In Spain, no, I don't think there are other adaptations. In Italy, yes. In France. Some in Portuguese, German, but no. I think this is first one in Spain. I hope they will do more.

MT: I hope so too. Marble deals with two men and two women in their forties. What motivated you to write a play about mid-life crisis?

MC: I was probably going through one. Ha ha! I was talking to an actress I know, Fiona Shaw, a very well-known Irish actress. She does a lot of classical roles in many films. I worked with her on Woman and Scarecrow, she was in that, and I was chatting to her one evening and she told me a story that Ted Hughes had told her at a poetry reading where they were reading together. He was reading some translations of Icelandic poetry and told Fiona a story that goes like this: there was an Icelandic farmer and an Icelandic fisherman and they were great friends and the farmer told the fisherman: "You know, I dreamed last night I was making love to your wife", and the fisherman turns round and says: "That is really strange because last night my wife dreamed she was making love to you ...". Fiona said that that would be a fantastic opening for a play! That is where it came from. So, I have Fiona to thank for that.

MT: One of the most difficult things when writing is to render dialogue in a believable, realistic way. Sometimes, you read some dialogues and they sound artificial, but in Marble, the dialogue is very realistic, very spontaneous. Do you have a natural ear for dialogue or have you had some training? I find it very difficult to reproduce a conversation.

MC: I'm not really that concerned with reproducing. Yes, you want them natural, but because it is artificial, it's always going to be slightly stilted. So, what you want is for it to be natural and flowing, and yet have the freedom to contain what you want to get across, which may or may not be natural and flowing. To make it appear natural. That is craft, that is one of the tools that you learn as you go along, and by redrafting. When I write I always talk everything out, because it is by hearing that I hear the glitch. I'll hear the rhythm, and I like to think that my ear is getting better, but that may be just vanity.

MT: We're coming to the last few questions. Could you say anything about your next play? How does it relate to its predecessors?

MC: Oh, God. It is a mess. I can say that. I am in the draft stage really. It's for the Abbey Theatre and beyond that, it has about ten characters. It is from a Greek myth, but I am just taking the bits I want, as usual. Beyond that, I really can't say.

MT: Good luck with that. Thank you so much for this interview, Marina Carr. I wish you all the best for your future work.

MC: Thank you very much, Melania. 
* The research on which this paper is based was funded by project APPI17/06 and the research group grant EGI16/31, and is in tune with the aims of the Centre of Irish Studies Banna/Bond (EFACIS). I wish to express my deepest gratitude to Irish writer Marina Carr and Alwyn Harrison for their helpful thoughts, comments, and suggestions. I also like to thank Spanish theater director Antonio C. Guijosa, actor Pepe Viyuela and screenplay writer Bernardo Sánchez for their generosity and disinterested help with the play Mármol.

\section{Notes}

\footnotetext{
${ }^{1}$ For further reference on Marina Carr as a major new voice in Irish Drama, see Sternlicht (2010).

${ }^{2}$ For further reference on this issue, see Muse (2011).

${ }^{3}$ For further reference on travellers, see Lanters (2008).
}

\section{Works Cited}

Carr, Marina. Plays One: Low in the Dark. The Mai. Portia Coughlan. By the Bog of Cats. London: Faber and Faber, 1999.

Carr, Marina. Plays Two: On Raftery Hill. Ariel. Woman and Scarecrow. The Cordelia Dream. Marble. London: Faber and Faber, 2009.

Carr, Marina. Plays Three: Sixteen Possible Glimpses. Phaedra Backwards. The Map of Argentina. Hecuba. Indigo. London: Faber and Faber, 2015.

Lanters, José. The 'Tinkers' in Irish Literature. Dublin: Irish Academic Press, 2008.

Muse, Amy. "Irish Appropriation of Greek Tragedy (review)". New Hibernia Review 15. 4 (2011): 147-148.

Sternlicht, Sanford. Modern Irish Drama: W. B. Yeats to Marina Carr. 2nd ed. Syracuse, New York: Syracuse University Press, 2010.

Received: 4 August $2018 \quad$ Accepted: 23 November 2018

Melania Terrazas Gallego is Senior Lecturer in English Studies at the University of La Rioja (Spain). She is the author of Relational Structures in Wyndham Lewis's Fiction: Complexity and Value (Lincom Europa, 2005) and helped set up the Wyndham Lewis Project website. She has published essays on Applied Linguistics (vocabulary knowledge and motivation) and extensively on British Modernism and a number of Irish authors and film directors (gender, satire theory, migration and trauma). She is on the Executive Board of AEDEI (The Spanish Association for Irish Studies) and is Head of the Centre of Irish Studies BANNA/BOND (EFACIS) at the University of La Rioja. She was the editor of Journal of English Studies from 2009 to 2012, and guest editor of the special issue of Estudios Irlandeses, 13.2, titled Gender Issues in Contemporary Irish Literature (2018). At present, she is finishing the edition of a volume on trauma and identity issues in contemporary Irish culture.

melania.terrazas@unirioja.es 